\title{
Pengembangan Pariwisata dengan Mendorong Ekonomi Kreatif Melalui Festival Balap Sampan Mini dan Inovasi Produk UKM Desa Paremas
}

Muhammad Ridwan Rafsanjani1, Yulia Rahmah2, Jazera Alfani2, Erich Efendi Mahesa3 , Alamsyah Mustika Wardani3 ${ }^{3}$ Imam Rustandi3 ${ }^{3}$, Cok Istri Wulandari3 ${ }^{3}$ Abdul Jihad3, Muzalli Andrean', Ilham Kurniawan', Nurkomalasari6, Tri Mei Elita ${ }^{6}$, Anggia Muawwadatul Audini', Putri Martina Lianti ${ }^{7}$, Saprizal Hadisaputra ${ }^{8}$

${ }^{1}$ Hubungan Internasional, Universitas Mataram, Indonesia
2 Ilmu Komunikasi, Universitas Mataram, Indonesia
${ }^{3}$ Fakultas Hukum, Universitas Mataram, Indonesia
${ }^{4}$ Fakultas Teknik, Universitas Mataram, Indonesia
${ }^{5}$ Fakultas Peternakan, Universitas Mataram, Indonesia
${ }^{6}$ Fakultas Ekonomi \& Bisnis, Universitas Mataram, Indonesia
${ }^{7}$ Fakultas Pertanian, Universitas Mataram, Indonesia
${ }^{8}$ Fakultas Keguruan dan Ilmu Pendidikan, Universitas Mataram, Indonesia
DOI: $10.29303 /$ ujcs.v2i4.55

\section{Article Info}

Received: August 21, 2021

Revised: October 25, 2021

Accepted: December 2, 2021

\begin{abstract}
Paremas Village is one of the villages located in Jerowaru District, East Lombok Regency, West Nusa Tenggara Province. This village has a lot of potential for natural wealth and local cultural wisdom, but Paremas Village is still not widely known by the wider community. The tourism arrangement that is still lacking makes tourism in Paremas Village fairly unfeasible. Therefore, the purpose of the New Normal Era Thematic Community Service Program at the University of Mataram for the July-August 2021 period is to develop tourism in Paremas Village by developing tourism by encouraging the Creative Economy Industry through the Festival Balap Sampan Mini Desa Paremas and product innovation of Kerupuk Cangkang Kepiting. The methods used are survey, observation, practice, documentation, and promotion. The results obtained are the re-emergence of the community's spirit to preserve traditions and increase community creativity in producing sampan mini and innovate by adding variants of Kerupuk Cangkang Kepiting. By encouraging the development of the creative economy industry in Paremas Village, it is hoped that it can encourage the community to be more productive with every
\end{abstract} potential they have and improve the welfare of the community

Keywords: Paremas Village; Mini Canoe Racing Festival; innovation; Creative Economy; Tourism

Abstrak: Desa Paremas merupakan salah satu desa yang berlokasi di Kecamatan Jerowaru, Kabupaten Lombok Timur, Provinsi Nusa Tenggara Barat. Desa ini menyimpan potensi kekayaan alam serta kearifan budaya lokal yang cukup banyak, namun sampai sekarang Desa Paremas masih belum banyak dikenal oleh masyarakat luas. Penataan wisata yang masih kurang menjadikan wisata yang ada di Desa Paremas ini terbilang belum layak. Oleh karena itu, tujuan dari KKN Tematik Era New Normal Universitas Mataram Periode Juli-Agustus 2021 adalah untuk mengembangkan wisata yang ada di Desa Paremas dengan melakukan pengembangan pariwisata dengan mendorong Industri Ekonomi Kreatif Melalui Festival Balap Sampan Mini Desa Paremas dan inovasi produk Kerupuk Cangkang Kepiting. Metode yang digunakan yaitu survey, observasi, praktik, dokumentasi, dan promosi. Hasil yang didapat yaitu munculnya kembali semangat masyarakat untuk melestarikan tradisi dan peningkatan kreativitas masyarakat dalam memproduksi sampan mini serta melakukan inovasi dengan menambahkan varian produk Kerupuk Cangkang Kepiting. Dengan mendorong pengembangan industri ekonomi kreatif yang ada di Desa Paremas diharapkan dapat mendorong masyarakat untuk lebih produktif dengan setiap potensi yang mereka miliki serta meningkatkan kesejahteraan masyarakat

Kata Kunci: Desa Paremas; Festival Balap Sampan Mini; Inovasi; Ekonomi Kreatif; Pariwisata

Citation: Rafsanjani, M. R. ., Rahmah, Y. ., Alfani, J. ., Mahesa, E. E. ., Wardani, A. M. ., Rustandi, I. ., Wulandari, C. I. ., Jihad, A. ., Andrean, M. ., Kurniawan, I. ., Nurkomalasari, N., Elita, T. M. ., Audini, A. M. ., Lianti, P. M. ., \& Hadisaputra, S. . (2021). Pengembangan Pariwisata dengan Mendorong Ekonomi Kreatif Melalui Festival Balap Sampan Mini dan Inovasi Produk UKM Desa Paremas. Unram Journal of Community Service, 2(4), 99-104. https://doi.org/10.29303/ujcs.v2i4.55

Email: alamwardani3@gmail.com (*Corresponding Author) 


\section{Pendahuluan}

Pariwisata merupakan suatu proses kepergian sementara dari seseorang atau lebih menuju tempat lain di luar tempat tinggalnya. Adapun dorongan kepergiannya adalah karena berbagai kepentingan baik karena kepentingan ekonomi, sosial, kebudayaan, politik, agama, kesehatan, maupun kepentingan lain seperti karena sekedar ingin tahu, menambah pengalaman ataupun belajar (Suwantoro, 2004).

Dewasa ini pariwisata seolah telah bertransformasi menjadi kebutuhan pokok masyarakat sebagai obat dari kejenuhan rutinitas pekerjaan. Berdasarkan letak geografis klasifikasi jenis pariwisata dibagi menjadi pariwisata lokal (local tourism), pariwisata regional (regional tourism), pariwisata nasional (national tourism), pariwisata internasional regional (regional- international tourism), dan pariwisata international (international tourism) (Suwena \& Widyatmaja, 2017). Intensitas perjalanan wisatawan domestik mengalami peningkatan sebesar lebih dari 21\% dalam kurun waktu lima tahun (2013-2018) dikutip dari data Badan Pusat Statistik yang dijabarkan oleh (Kusnandar, 2019). Peningkatan tersebut tidak terlepas dari keberagaman atraksi wisata baik alamiah maupun hasil cipta manusia.

Adapun pengelompokan jenis pariwisata berdasarkan objeknya yaitu wisata seni budaya (cultural tourism), wisata kesehatan (Recreational tourism), wisata niaga (commercial tourism), wisata olahraga (sport tourism), wisata politik (political tourism), wisata sosial (social tourism), wisata religi (religion tourism), dan wisata bahari (marine tourism) (Suwena \& Widyatmaja, 2017). Keberagaman tersebut memungkinkan setiap daerah untuk mengembangkan sektor pariwisata sesuai dengan potensi dan karakteristik masing-masing.

Keberagaman tersebut juga memberikan peluang terhadap satu wilayah dalam mengembangkan industri ekonomi kreatif nya. Adapun pengertian dari Ekonomi kreatif sendiri ialah aktivitas perekonomian yang lebih mengandalkan ide atau gagasan (kreatif) untuk mengelola material yang bersumber dari lingkungan di sekitarnya menjadi bernilai tambah ekonomi (Howkins, 2001). Selain itu terdapat pendapat lain yaitu ekonomi kreatif merupakan "penciptaan nilai tambah yang berbasis ide yang lahir dari kreativitas sumber daya manusia (orang kreatif) dan berbasis ilmu pengetahuan, termasuk warisan budaya dan teknologi (Kemenparekraf, dikutip El Hasanah, 2018). Sejalan dengan hal tersebut pengembangan pariwisata yang bersinergi dengan ekonomi kreatif dapat diterapkan di Desa Paremas

Desa Paremas merupakan salah satu desa kecil yang berada di Kecamatan Jerowaru, Kabupaten Lombok Timur yang terbentuk dari hasil pemekaran Desa Pemongkong pada Tahun 2011 tepatnya pada Tanggal 11 November 2011 dengan Peraturan Bupati Lombok Timur Nomor 12 Tahun 2009. Desa Paremas pada dasarnya memiliki banyak sekali potensi yang tentunya dapat dikembangkan dan dimanfaatkan guna untuk kesejahteraan masyarakatnya. Adapun potensi yang dominan dimiliki oleh Desa Paremas yaitu wisata alam salah satunya wisata pantai dan hutan mangrove. Dengan wilayah Desa Paremas yang terletak di pesisir pantai dan dikelilingi oleh perairan melahirkan tradisi balap sampan mini yang awalnya hanya sebagai media hiburan bagi masyarakat. Hal tersebut tentunya melahirkan pula para pengrajin sampan mini dengan ide dan aktivitasnya masing-masing. Selain itu juga melimpahnya sumber daya hasil laut di sekitar Desa Paremas menjadikan produk olahan hasil laut dapat menjadi potensi tersendiri bagi Desa Paremas.

Tradisi balap sampan yang semakin hari semakin luntur sebagai akibat dari minimnya support dari berbagai pihak menjadikan urgensi dari pengadaan Festival Balap Sampan Mini oleh Kelompok KKN Universitas Mataram Desa Paremas sangat penting dilakukan. Selain itu pula produk unggulan dari Desa Paremas yaitu Kerupuk Cangkang Kepiting masih bisa dilakukan inovasi untuk meningkatkan penjualan dan pendapatan UKM Desa.

\section{Metode}

Kegiatan KKN di Desa Paremas pada dasarnya tetap dilaksanakan sesuai dengan protokol kesehatan mengingat jangka waktu pelaksanaan KKN masih dalam masa pandemi Covid-19. Selanjutnya kegiatan pelaksanaan KKN dimulai dari melakukan survey terkait kondisi desa serta menggali potensi yang dapat dikembangkan menjadi daerah wisata yang dapat menarik wisatawan baik lokal maupun mancanegara. Selain itu, kami juga melakukan wawancara serta meminta data kepada pihak kepala desa terkait potensi-potensi yang ada di Desa Paremas. Sehingga dari hasil kegiatan tersebut kami mendapatkan informasi untuk dapat menyusun program kerja selama melakukan kegiatan di Desa Paremas.

Materi persiapan meliputi pengumpulan informasi terkait potensi desa, data-data desa dan materi dari sumber terpercaya yang digunakan dalam kegiatan KKN. Sebelum terjun ke desa, mahasiswa diberikan pembekalan terlebih dahulu panitia kegiatan KKN dan Dosen Pembimbing Lapangan (DPL).

Adapun dalam mendorong industri ekonomi kreatif melalui festival balap sampan mini Desa Paremas dilakukan melalui berbagai tahapan seperti 
melakukan diskusi dengan masyarakat terkait dengan sejarah, persiapan, dan pelaksanaan terkait dengan Festival Balap Sampan Mini. Segala kegiatan yang berkaitan dengan pelaksanaan festival balap sampan tetap mempertimbangkan tradisi yang telah ada dan disesuaikan dengan protokolkesehatan.

Selain itu dalam melakukan inovasi terhadap produk Kerupuk Cangkang Kepiting, dilakukan dengan diskusi tahap wala mengenai inovasi, persiapan bahan, dan beberapa kalipercobaan.

\section{Hasil dan Pembahasan}

Desa Paremas sebagai desa wisata dapat dipahami melalui konsep desa wisata, yaitu dimana adanya suatu kelompok kecil wisatawan yang tinggal di dalam atau di dekat desa terpencil sekaligus belajar mengenai kehidupan tradisional sehari-hari masyarakat lokalnya. Dengan kata lain, desa wisata merupakan suatu tempat atau desa yang mempunyai ciri dan nilai tertentu yang dijadikan daya tarik bagi wisatawan. Kehidupan pedesaan masyarakat lokal menjadi daya tarik utama yang dicari oleh banyak wisatawan, yang mereka tidak temui di perkotaan.

Dalam pengertian lain, desa wisata diartikan sebagai daerah atau destinasi tujuan wisata yang memiliki daya tarik wisata, fasilitas, dan aksesibilitas yang dikemas dalam struktur kehidupan masyarakat lokal dengan unsur tradisional. Desa wisata jelas berbeda dengan desa biasanya karena memiliki potensi ataupun produk pariwisata yang ditawarkan. Desa wisata memiliki temanya masing- masing sesuai potensi pariwisata yang ingin ditonjolkan, seperti desa kreatif, desa hijau, desa gerabah, desa kerajinan, dan lain sebagainya (Tim KKN-PPM, 2012).

Desa wisata sendiri memiliki beberapa komponen yang menjadi potensi pengembangan pariwisata, salah satunya yaitu Atraksi. Atraksi adalah kehidupan rutin sehari-hari masyarakat lokal desa yang dimana dalam kegiatannya wisatawan dapat berpartisipasi. Setiap desa memiliki kebiasaan yang berbeda dan unik satu sama lain, yang mana hal ini menjadikan sebuah desa wisata memiliki daya tarik tersendiri bagi wisatawan, yang memungkinkan mereka untuk ikut dalam kegiatan masyarakat lokal. Pengalaman inilah yang tidak mungkin didapatkan wisatawan di Kota asalnya.

Untuk menjadi Desa wisata bagi suatu desa juga haruslah memiliki keunikan dan kekhasan tersendiri dibanding desa lainnya. Oleh karenanya, desa wisata memiliki kriteria-kriteria berupa potensi dan daya tarik wisata yang khas dan berkarakteristik, baik dari segi lingkungan maupun sosial budaya masyarakat lokalnya.
Desa Paremas memiliki banyak spot yang berpotensi wisata salah satunya adalah Hutan Mangrove. Namun tidak adanya perhatian dari pemerintah setempat membuat spot yang berpotensi wisata tersebut tidak bisa berkembang. Berangkat dari hal tersebut kami berpikir bahwa harus ada faktor yang menarik wisatawan ke Desa Paremas.

Salah satunya yang ada di Desa Paremas yaitu tradisi balap sampan mini yang telah ada sedari dulu. Balap sampan mini memiliki potensi untuk menarik wisatawan berkunjung ke Desa Paremas. Namun tradisi tersebut perlahan mulai luntur karena minimnya dukungan dari pemerintah dan kendala ekonomi ditambah lagi dengan pandemi Covid-19. Berdasarkan dari alasan tersebut, Kelompok KKN Tematik Era New Normal Desa Paremas berinisiatif untuk membangun kembali semangat masyarakat agar tradisi tersebut tidak hilang begitu saja dan menjadikan balap sampan mini sebagai pemantik untuk pengembangan potensi wisata lain yang ada di Desa Paremas.

Pelaksanaan Festival Balap Sampan Mini memberikan keterlibatan penuh pemuda dan masyarakat Desa Paremas. Kelompok KKN Tematik Era New Normal Desa Paremas memanfaatkan hal tersebut untuk menanamkan semangat dan pemahaman pemuda dan Masyarakat untuk menjadikan festival balap sampan mini tersebut event yang berkelanjutan.

Informasi mengenai tradisi balap sampan mini yang di dapat dari hasil diskusi dengan masyarakat ini menjadi salah satu program kerja tambahan kami, mengingat urgensi balap sampan ini sebagai tradisi yang khas dan unik yang hanya dimiliki oleh Desa Paremas. Dalam pelaksanaannya Kelompok KKN Desa Paremas mendapat respon positif dari setiap masyarakat desa. Sejalan dengan hal tersebut masyarakat pun berinisiatif untuk membantu dan membimbing Kelompok KKN untuk mensukseskan pelaksanaan festival tersebut.

Pada tahap persiapan, Kelompok KKN banyak melakukan diskusi dengan tokoh masyarakat Desa Paremas Seperti Kepala Desa, Kepala-Kepala Dusun, dan para pemuda desa terkait peraturan dan tata laksana perlombaan. Tahap pra-acara dimulai dengan mensosialisasikan pada masyarakat mengenai penyelenggaraan Festival Balap Sampan Mini Desa Paremas dan menyebarkan pamflet mengenai pembukaan pendaftaran acaratersebut. 


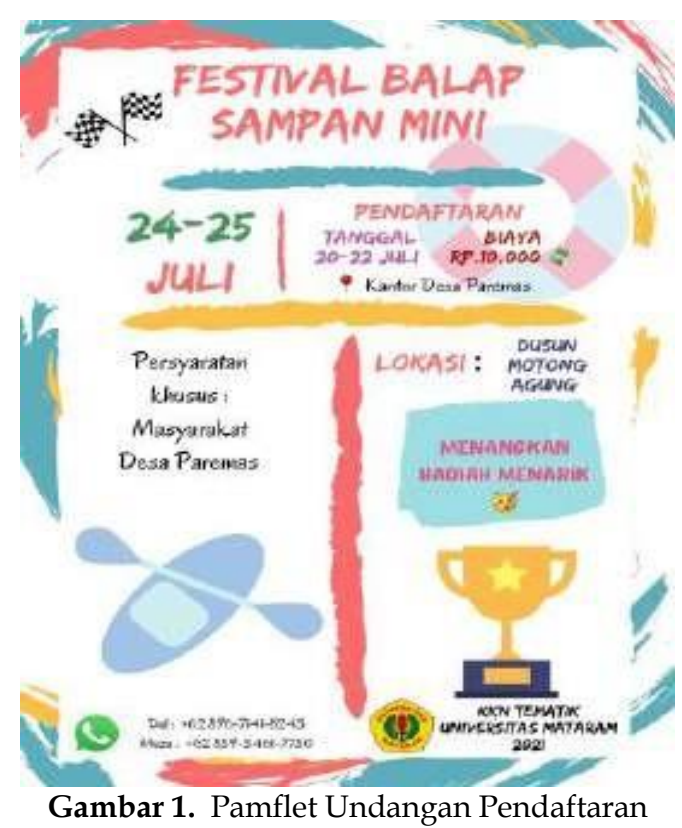

Setelah dilakukan pembukaan pendaftaran berbagai persiapan dilakukan seperti menyiapkan lintasan balap sampan, technical meeting dan menyiapkan hadiah bagi para pemenang. Acara Festival Balap Sampan Mini Desa Paremas ini diselenggarakan sejak tanggal 20-22 Juli 2021 untuk melakukan pendaftaran, technical meeting pada $23 \mathrm{Juli}$ dan Festival dilaksanakan pada 24-25 Juli 2021.

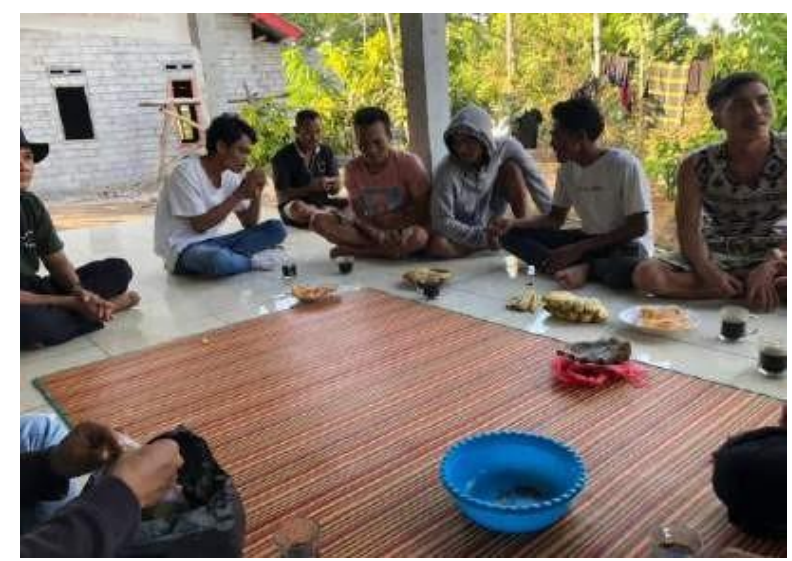

Gambar 2. Pelaksanaan Technical Meeting

Mengingat acara yang terbilang singkat dan mendadak dengan dikeluarkan surat penarikan Kelompok KKN dari Universitas Mataram seharusnya menjadikan ekspektasi panitia Festival mengenai jumlah peserta lomba tidak terlalu banyak. Namun kenyataannya antusiasme masyarakat Desa Paremas terhadap Festival ini sangat tinggi sehingga mereka menyanggupi persiapan yang singkat dan jumlah peserta menjadi di luar ekspektasi panitia, dimana saat itu terdapat 23 kapal yang mendaftar untuk menjadi peserta balap sampan mini. Selain menentukan pemenang berdasarkan kecepatan dan ketepatan mencapai garis finish, panitia juga menambah kategori pemenang favorit. Kategori pemenang favorit ditentukan berdasarkan kerapian, keunikan, dan keestetikan sampan mini, dimana hal tersebut dilakukan untuk mengasah kreatifitas pengrajin sampan mini. Penyelenggaraan tetap dilaksanakan sesuai dengan protokol kesehatan dengan membagikan masker secara gratis kepada peserta lomba dan menghimbau masyarakat untuk tidak berkerumun dan tetap menjaga jarak.

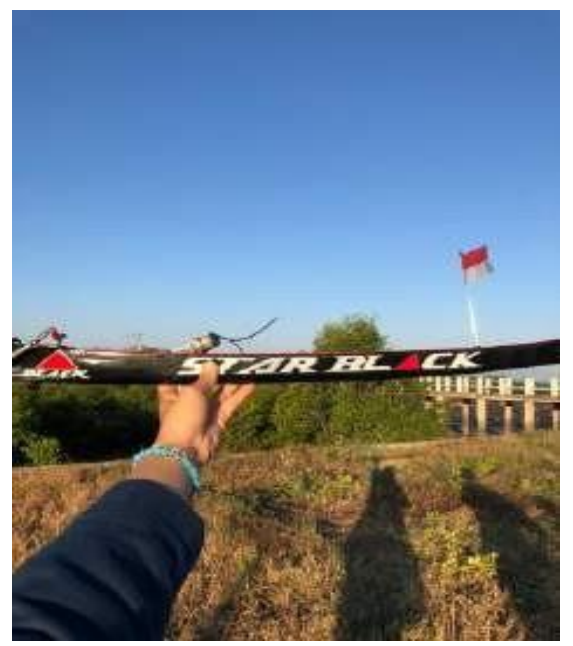

Gambar 3. Foto Sampan

Adapun hasil yang didapat atas terselenggaranya Festival Balap Sampan Mini Desa Paremas oleh Kelompok KKN Tematik Universitas Mataram Desa Paremas yaitu kembalinya semangat masyarakat untuk melestarikan tradisi balap sampan mini yang dapat menjadi salah satu daya tarik wisata yang unik dan hanya ada di Desa Paremas. Masyarakat pun kembali menyelenggarakan acara serupa untuk memeriahkan hari kemerdekaan Republik Indonesia ke 76 dimana acara dilaksanakan pada tanggal 14 Agustus 2021.

Atas penghargaan masyarakat terhadap Kelompok KKN Desa Paremas yang menghidupkan kembali semangat menjaga tradisi balap sampan tersebut, masyarakat pun turut mengundang Kelompok KKN untuk berpartisipasi kembali dengan memberikan undangan secara formal. Selain itu pula dengan kembalinya semangat masyarakat untuk kembali melestarikan dan menggiati balap sampan ini otomatis memunculkan pengrajin sampan mini dengan kreativitas tinggi yang mengarahkan pada munculnya industri ekonomi kreatif dalam bidang pembuatan sampan mini. Sampan mini yang dijadikan masyarakat desa tentunya tidak hanya untuk diperlombakan dalam sirkuit balapan, namun bisa dijadikan sebagai oleh-oleh dan buah tangan khas Desa Paremas untuk penghias 
ruangan dan sebagainya. Tentunya dengan adanya industri ekonomi kreatif dalam pembuatan sampan mini menjadi potensi tersendiri bagi Desa Paremas yang menjadi salah satu daya tarik wisata yang ada di Desa Paremas.

\section{Inovasi Produk Kerupuk Cangkang Kepiting}

Inovasi merupakan ciptaan-ciptaan baru (dalam bentuk materi maupun intangible) yang memiliki nilai ekonomi yang (signifikan), yang pada umumnya dilakukan oleh perusahaan atau kadang-kadang oleh para individu (Edquist, 2001).

Sehubungan dengan hal tersebut Desa Paremas tidak hanya memiliki potensi tempat wisata dan atraksi wisata saja, tetapi desa ini sudah dikenal oleh banyak orang sebagai desa yang memproduksi kerupuk yang berasal dari hasil laut yakni dari cangkang kepiting. Desa ini memiliki inovasi terbaru yang mampu mengolah dan memproduksi hasil laut menjadi makanan yang enak dan digemari oleh banyak konsumen hal ini tentunya dapat meningkatkan perekonomian dengan membuat inovasi terhadap sebuah produk.

Desa Paremas merupakan desa yang dikenal memiliki potensi sumber daya alam yang berlimpah salah satunya adalah hasil laut. Hasil laut ini bisa dimanfaatkan oleh masyarakat untuk dijadikan produk olahan. Produk olahan ini berbahan dasar dari limbah cangkang kepiting. Cangkang kepiting ini diolah menjadi sebuah makanan yang penuh protein salah satunya adalah dijadikan sebagai olahan kerupuk yang enak dan gurih. Kerupuk ini biasa disebut dengan nama kerupuk cangkang kepiting. Kerupuk cangkang kepiting ini memiliki empat varian rasa yakni: Cumi, jeruk, pedas dan original. Kerupuk ini merupakan sebuah produk yang didirikan oleh sekelompok ibu-ibu UKM “Ingin Maju” Desa Paremas, Dusun Keranji, Kecamatan Jerowaru Kabupaten Lombok Timur.

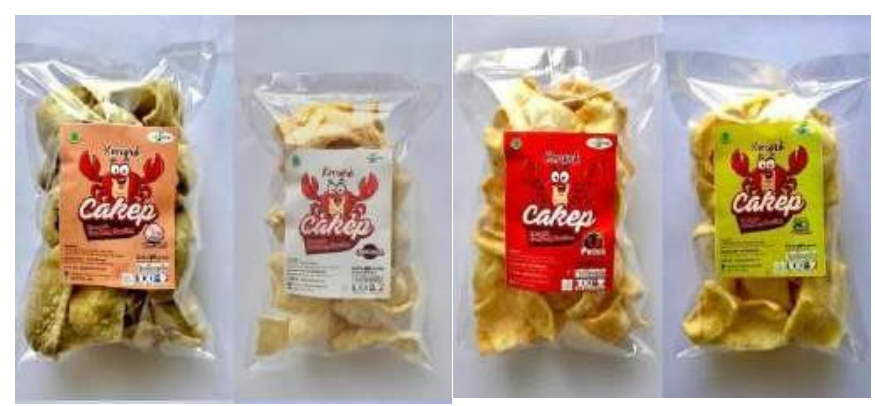

Gambar 4. Produk Kerupuk Cangkang Kepiting

Pembuatan kerupuk cangkang kepiting di proses dalam waktu seminggu dua kali tergantung pemesan para konsumen. Proses pembuatan kerupuk cangkang kepiting ini sangat mudah. Dengan menyiapkan beberapa bahan antara lain: tepung terigu, tepung tapioka dan cangkang kepiting yang sudah di haluskan dan bumbu-bumbuan khas serta tambahan varian rasa cumi, original, pedas, dan jeruk yang membuat produk kerupuk cangkang kepiting ini menjadi lebih enak, gurih dan nikmat.

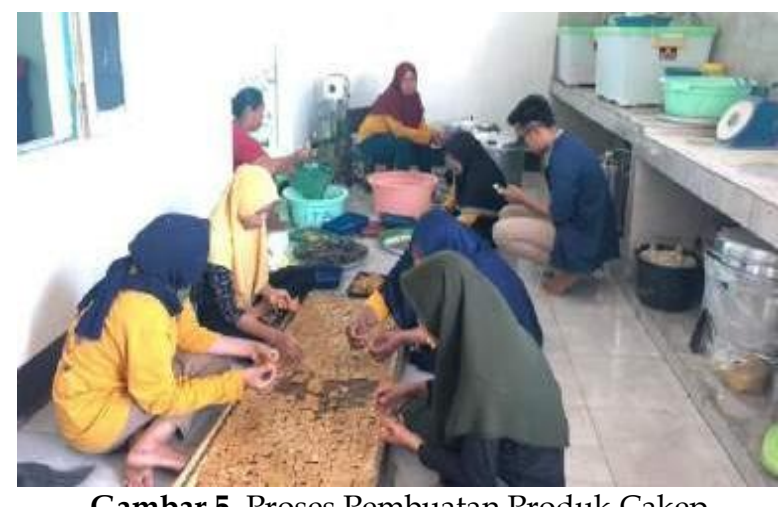

Gambar 5. Proses Pembuatan Produk Cakep

Dengan adanya pembuatan produk cangkang kepiting ini memberikan keterlibatan pada kelompok KKN Tematik Era New Normal Desa Paremas memanfaatkan hal tersebut untuk memberikan kelompok UKM "ingin Maju" inovasi terbaru terkait dengan rekomendasi varian rasa yang sekarang ini sangat banyak disukai oleh masyarakat yakni dengan menambahkan varian bubuk cabe pedas pada kerupuk cangkang kepiting.

Terkait dengan inovasi terbaru kerupuk cangkang kepiting dan diskusi dengan ibu- ibu dari kelompok UKM "Ingin Maju" menjadi salah satu program kerja terkait dengan inovasi produk cangkang kepiting sebagai bentuk varian yang banyak digemari oleh berbagai lapisan konsumen.

Adapun Percobaan dilakukan dengan mencocokkan rasa produk dengan penambahan bubuk cabai yang dibuat sendiri oleh Kelompok KKN Desa Paremas. Kelompok KKN Desa Paremas memilih untuk menggunakan bubuk cabai yang pedasnya alami dari cabai dibandingkan dengan perasa pedas buatan lainnya agar kualitas dan nilai gizi dari inovasi Kerupuk Cangkang Kepiting dapat dipertahankan. Setelah dilakukan percobaan pembuatan bubuk cabai, hasil percobaan tersebut diberikan kepada ibu Harniati selaku ketua UKM Ingin Maju, dan ibu Harniati memberikan tanggapan positif atas inovasi tersebut. 

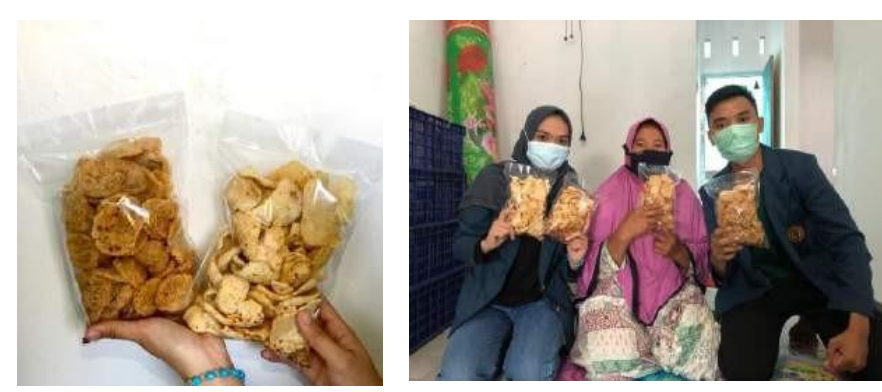

Gambar 6. Inovasi Produk Kerupuk Cakep

Dengan adanya inovasi tersebut, industri ekonomi kreatif unggulan Desa Paremas tersebut diharapkan mampu mendapatkan lebih banyak keuntungan dengan bertambahnya varian rasa yang sesuai dengan selera masyarakat. Kerupuk Cangkang Kepiting yang menjadi produk khas Desa Paremas dapat menjadi salah satu potensi yang dapat menarik wisatawan untuk berkunjung langsung ke Desa Paremas. sehubungan dengan hal tersebut, Kelompok KKN Desa Paremas juga turut mempromosikan baik Festival Balap Sampan Mini maupun Kerupuk Cangkang Kepiting melalui media sosial untuk mewujudkan pengembangan ekonomi kreatif sebagai salah satu bagian dari pengembangan pariwisata Desa Paremas. Adapun promosi tersebut dapat di lihat pada akun instagram @kkn_paremas21 dan channel YouTube KKN Desa Paremas 2021.

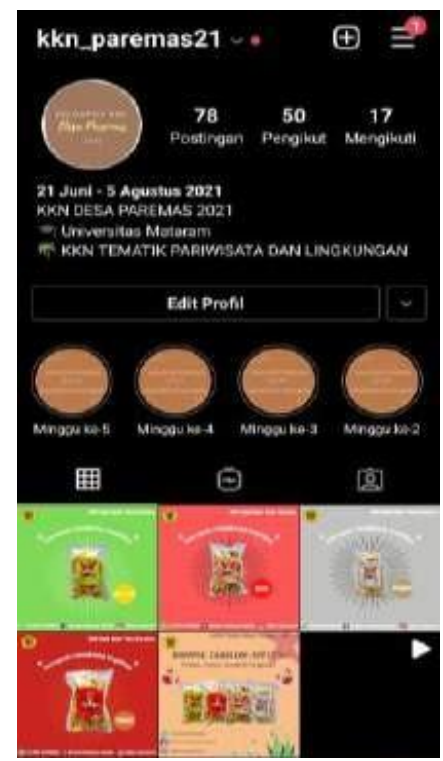

Gambar 7. Promosi Festival Balap Sampan Mini dan Produk Kerupuk Cakep melalui Instagram dan Youtube

\section{Kesimpulan}

Berdasarkan isi dan pembahasan di atas dapat disimpulkan bahwa pengembangan pariwisata dengan mendorong industri ekonomi kreatif melalui Festival Balap Sampan Mini Desa Paremas dan inovasi produk Kerupuk Cangkang Kepiting merupakan salah satu cara yang tepat untuk memperkenalkan dan mengembangkan Desa Paremas sebagai salah satu desa wisata yang memiliki keunikan tersendiri. Industri ekonomi kreatif seperti melalui pengadaan festival balap sampan mini yang mendorong kreativitas masyarakat dalam membuat sampan mini dengan nilai jual yang bersaing dan inovasi Kerupuk Cangkang Kepiting yang khas tentunya menjadikan Desa Paremas sebagai salah satu desa wisata yang menarik. Melalui program kerja yang dijalankan selain sebagai media silaturahmi antara Kelompok KKN Universitas Mataram Desa Paremas dengan masyarakat desa, tentunya dapat memberikan manfaat yang besar dan berkelanjutan untuk meningkatkan kesejahteraan bersama khususnya masyarakat Desa Paremas.

Adapun saran yang dapat diberikan yaitu untuk masyarakat Paremas agar senantiasa menjaga tradisi yang sudah ada dan menjadi ciri khas Desa Paremas dan terus mengembangkan dan menyalurkan kreativitasnya untuk mewujudkan Desa Paremas sebagai desa yang berdikari dan memiliki industri ekonomi kreatif yang menjadi daya tarik wisata Desa. Untuk para pembaca diharapkan untuk selalu mendukung industri ekonomi kreatif lokal tidak hanya sebagai konsumen saja namun bisa juga berperan lebih dengan turut mempromosikan industri ekonomi kreatif lokal. Selain itu untuk kelompok KKN selanjutnya diharapkan untuk dapat melanjutkan semangat juang membantu masyarakat dan melanjutkan program kerja kelompok KKN saat ini yang masih belum maksimal mengingat terkendala situasi pandemi Covid-19 yang masih belum menemukan titik terang waktu berakhirnya.

\section{Daftar Pustaka}

$\begin{array}{lll}\text { Tim KKN-PPM. } & \text { (2012). Buku Pedoman } \\ \text { Umum } & \text { Desa } & \text { Wisata. } \\ \text { https://www.academia.edu/6423956/... } \\ \text { OaF4UuMc3FmAt54P. }\end{array}$

Suwantoro, G. (2004). Dasar-Dasar Pariwisata.Andi.

El Hasanah, L. L. N. (2018). Pengembangan Wirausaha Muda Ekonomi Kreatif Berbasis Budaya di Daerah Istimewa Yogyakarta. Jurnal Studi Pemuda, 4(2), 268. https://doi.org/10.22146/studipemudaugm.36 $\underline{812}$

Howkins, J. (2001). The Creative Economy: How People Make Money from Ideas. Allen Lane. London.

Kusnandar, V.B. (2019). Jumlah Perjalanan Wisatawan Nusantara 2018 Tumbuh 12\%. Databoks. Databoks. Retrieved from: https://databoks.katadata.co.id/...tumbuh-12 
Suwena, I.K., \& Widyatmaja, I.G.N. (2017).

Pengetahuan Dasar Ilmu Pariwisata (Revisi).

Pustaka Larasan. 